\title{
ANALYSIS OF NITRATE OCCURRENCE AND DISTRIBUTION IN GROUNDWATER IN THE GAZA STRIP USING MAJOR ION CHEMISTRY
}

\author{
H. BAALOUSHA
}

Received: $17 / 01 / 08$

Accepted: 24/01/08

\author{
Institute of Hydraulic Engineering and Water Resources \\ Management, Faculty of Civil Engineering \\ Aachen University of Technology (RWTH) \\ Mies-van-der-Rohe-St. 1, 52056 Aachen, Germany \\ *to whom all correspondence should be addressed: \\ Fax: +49-241- 8022348; e-mail: baalousha@web.de
}

\begin{abstract}
Nitrate in groundwater in the Gaza Strip, Palestine has become a serious problem in the last decade. As a result of extensive use of fertilizers, discharging of wastewater from treatment plants, and leakage of wastewater form cesspools, increased levels of nitrate up to $400 \mathrm{mg} / \mathrm{l}$ have been detected in groundwater. Nitrate concentrations more than $50 \mathrm{mg} \mathrm{I}^{-1}$ are very harmful to infant, foetuses, and people with health problems. The most efficient way to prevent nitrate impacts is to identify the sources of nitrate and to reduce them at the source. In this study, samples of groundwater from 63 wells were collected and chemically analyzed. Analysis of these samples revealed they have nitrate concentrations more than the maximum permissible limit recommended by World Health Organization (WHO). The major ion chemistry analysis was used to identify nitrate sources.
\end{abstract}

Based on the relation between land use and nitrate concentration in groundwater, sources of nitrate were identified. These sources are: (1) leakage from wastewater treatment plants, (2) leakage from cesspits, and (3) intensive agricultural activities. It was found that the leakage of wastewater from cesspits and over-loaded treatment plants has greater influence on groundwater nitrate contamination more than agricultural activities. This study shows the important role of the type of infiltrated water into the sub-soil, combined land use, in determining the source of nitrate in groundwater.

KEYWORDS: nitrate, groundwater pollution, Gaza Strip, geochemistry, environment.

\section{INTRODUCTION}

Human activities (e.g. agricultural practice, fertilizers application, wastewater discharge, etc.) have had a great influence on the quality of groundwater in different regions in the world. Nitrate groundwater pollution has become a serious problem because of its negative impacts. High concentrations of nitrate in the groundwater pose a serious threat to the quality of the groundwater resources, and consequently, to the public health.

Identification of the amount of nitrogen available in the soil is important. Then the calculation of crop requirement of nitrogen based on crop type should be made based on the estimation of nitrogen available in soil. After that, the required amount of nitrogen in form of fertilizer can be applied to crops. The application method of fertilizers has a great effect on the plant uptake of the applied fertilizers.

The Mediterranean coastal aquifer of the Gaza Strip is the only source of water supply for domestic, agricultural, and other use in the area. As a result of intensive agricultural activities, over-pumping, and sewerage outflow, the quality of groundwater has been severely affected in the last decade. According to the World Health Organisation (WHO), the nitrogen level in groundwater should not exceed $10 \mathrm{mg} \mathrm{l}^{-1}$ as $\mathrm{N}$ or $50 \mathrm{mg} \mathrm{l}^{-1}$ as nitrate $\left(\mathrm{NO}_{3}\right)(\mathrm{WHO}, 2004)$. However, levels of $300 \mathrm{mg} \mathrm{l}^{-1}$ of nitrate in groundwater are very common in many areas in the Gaza Strip. The high levels of nitrate in some areas of the Gaza Strip have resulted from 
intensive application of fertilizers and pesticides. In addition, improper discharge of wastewater without any treatment is very common in some areas in the Gaza Strip (e.g. Khan Yunis area). As a result, the levels of nitrate concentrations in aquifer of the study area are above the maximum permissible value.

Nitrate itself is not a poisonous substance, and it is not a problem for adults but it is very dangerous for infants under six months of age. Because of their small size and liquid-based diet, the infants are susceptible to interruption of body processes resulted from high nitrate in drinking water. In the first few months of infant life, there are certain bacteria that live in their digestive system. These bacteria convert the nitrate, which is not harmful, to nitrite. When blood absorbs nitrite, it combines with haemoglobin, which carries oxygen, and forms methemoglobin. Methemoglobin cannot carry oxygen, and thus, the infant body turns into blue. If that happens it may lead to death if not treated. Several cases of methemoglobin have been reported in the Gaza Strip in the last few years (Abu Maila et al., 2004).

Besides its harmful impact on infant, it is found that young animals are affected by nitrate the same way as babies. Adults with chronic health problems may be at higher risk from elevated nitrate/nitrite levels. Pregnant and nursing mothers should also avoid drinking water polluted with nitrate because of potential effects passed on to the foetus or infant. Some livestock have been known to abort foetuses because of drinking nitrate-polluted water. Moreover, the increased nitrate level in drinking water may adversely affect the central nervous system (Chern et al., 1999).

Identification of nitrate sources in groundwater is very essential to take the proper measures to eliminate nitrate pollution. Therefore, the objectives of this study are to analyse the nitrate sources in the study area and to find out how to reduce the high concentrations of nitrate in the groundwater.

\section{THE STUDY AREA AND HYDROGEOLOGY}

The Gaza Strip area is part of the Palestinian occupied territories, located at longitudes $31^{\circ}$ $30 '$ North and Longitude $34^{\circ} 28^{\prime}$ East. It is a very small area located at the eastern coast of the Mediterranean, about $40 \mathrm{~km}$ long and its width varies between 6 to $12 \mathrm{Km}$ (Figure. 1). The total area of the Gaza Strip is about $365 \mathrm{~km}^{2}$. More than 1.3 million inhabitants are living in this small area, according to 2004 statistics (PCBS 2004). The population density in the Gaza Strip, especially in the eight refugee camps, is the highest in the world. Because of its location, the Gaza Strip forms a transitional zone between the semi-humid coastal area in the north and the semi-arid Sinai desert in the south.

The geological components in the area consist of a littoral zone, a strip of dunes from Quaternary era situated on the top of a system of older Pleistocene beach ridge, and more to the east, gently sloping alluvial and loessial plains. The aquifer is composed of PliocenePleistocene calcareous sandstone, and layers of clays (EUROCONSULT and IWACO 1994).

The aquifer in the Gaza Strip is part of the coastal aquifer, which extends from Karmel Mountain in the north to Sinai desert in the south with a variable width and depth (Figure 2). The total area of the coastal aquifer is about $2000 \mathrm{~km}^{2}$ with a small part of it beneath the Gaza Strip. Alluvial sandstone and gravel from Tertiary era covered with Quaternary sand dunes are the main components of aquifer media (EUROCONSULT and IWACO 1994). The sand dunes extend along the shoreline up to few kilometres inland. The depth of the aquifer varies from about 170 meters at the shoreline to some few meters at the eastern boundary. Therefore, the thickness of the aquifer varies between $200 \mathrm{~m}$ in the west along the coastline to few meters in the east. There is a very thick impermeable clay layer from Neogene age underneath the aquifer and it is called "Saqyia Formation". This layer has a thickness that varies from 400 to 1000 meters and it forms the bed of the aquifer. There are a number of clay layers of variable thicknesses up to 20 meters that divide the aquifer into three main subaquifers (Figure 3 ). These clay layers are generally aquiclude and extend from the shoreline to $5 \mathrm{Km}$ inland. Therefore, the aquifer can be considered as unconfined in the eastern part and confined/unconfined multi-aquifer in the western part. The sub-aquifers, resulted from clay layers division, were classified into sub-aquifer $A$, which is at the top, sub-aquifer $B$ in the 
middle, and sub-aquifer $\mathrm{C}$ beneath. Groundwater flows usually in the east-west direction towards the sea (Al-Agha and El-Nakhal, 2004). However, groundwater flow direction may change locally due to over-pumping.

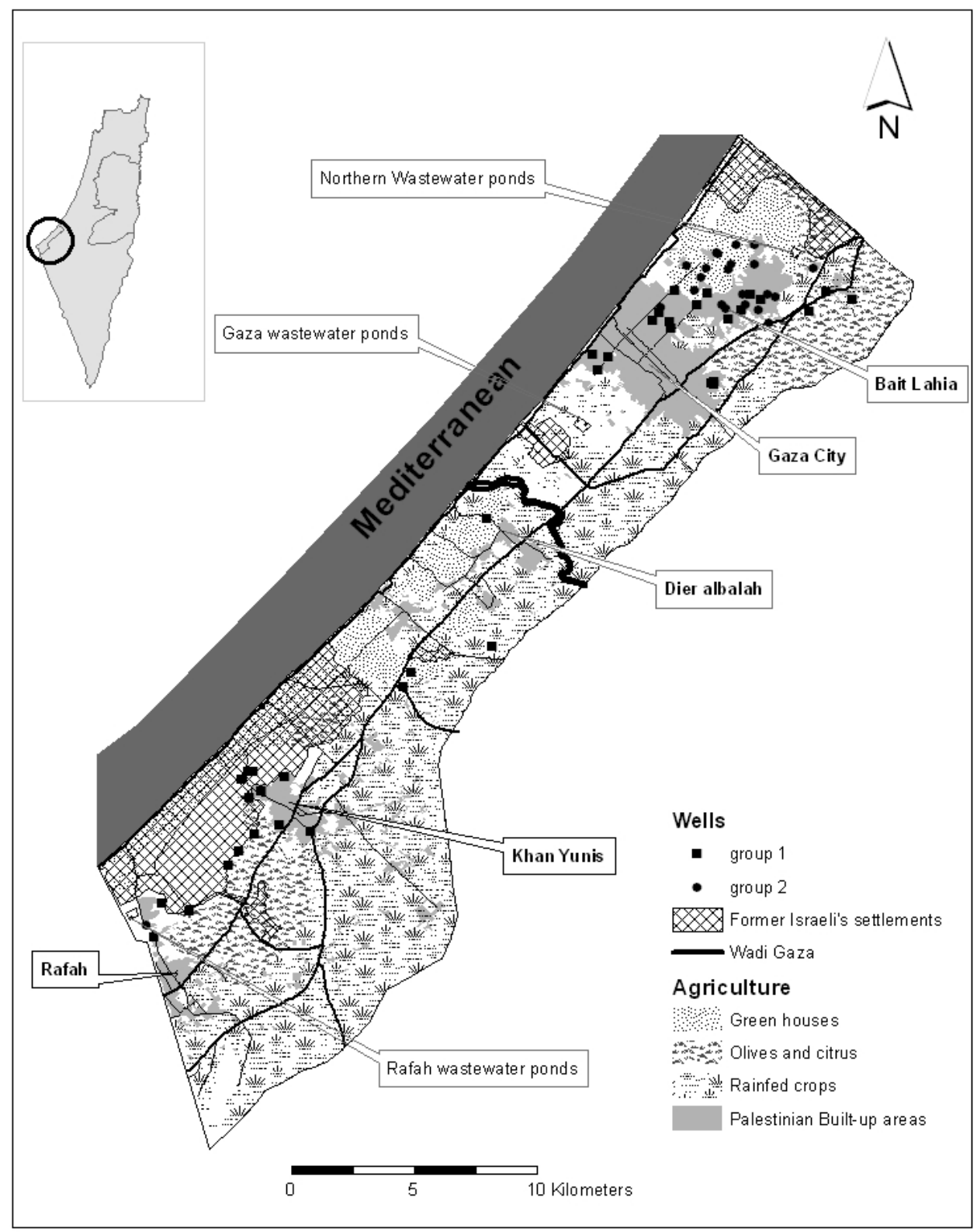

Figure 1. The study area, land use, and the locations of sampled wells

As there are no other sources of water in the Gaza Strip, the only mean of water supply is the coastal aquifer. The aquifer is recharged mainly by rainfall and other minor sources such as leakage of water system, irrigation return flow, and wastewater discharge. The average annual rainfall in the Gaza Strip varies between $500 \mathrm{~mm}$ in the north to $200 \mathrm{~mm}$ in the south. Thus, the average annual rainfall in the Gaza Strip based on 20 years average is $320 \mathrm{~mm} \mathrm{y}^{-1}$. The total amount of groundwater recharge from rainfall is about 43 million $\mathrm{m}^{3}$ per year (Baalousha, 2005). According to Metcalf and Eddy (2000), the irrigation return flow in the Gaza Strip varies between 20 and 25 million $\mathrm{m}^{3}$ (Metcalf and Eddy 2000) 


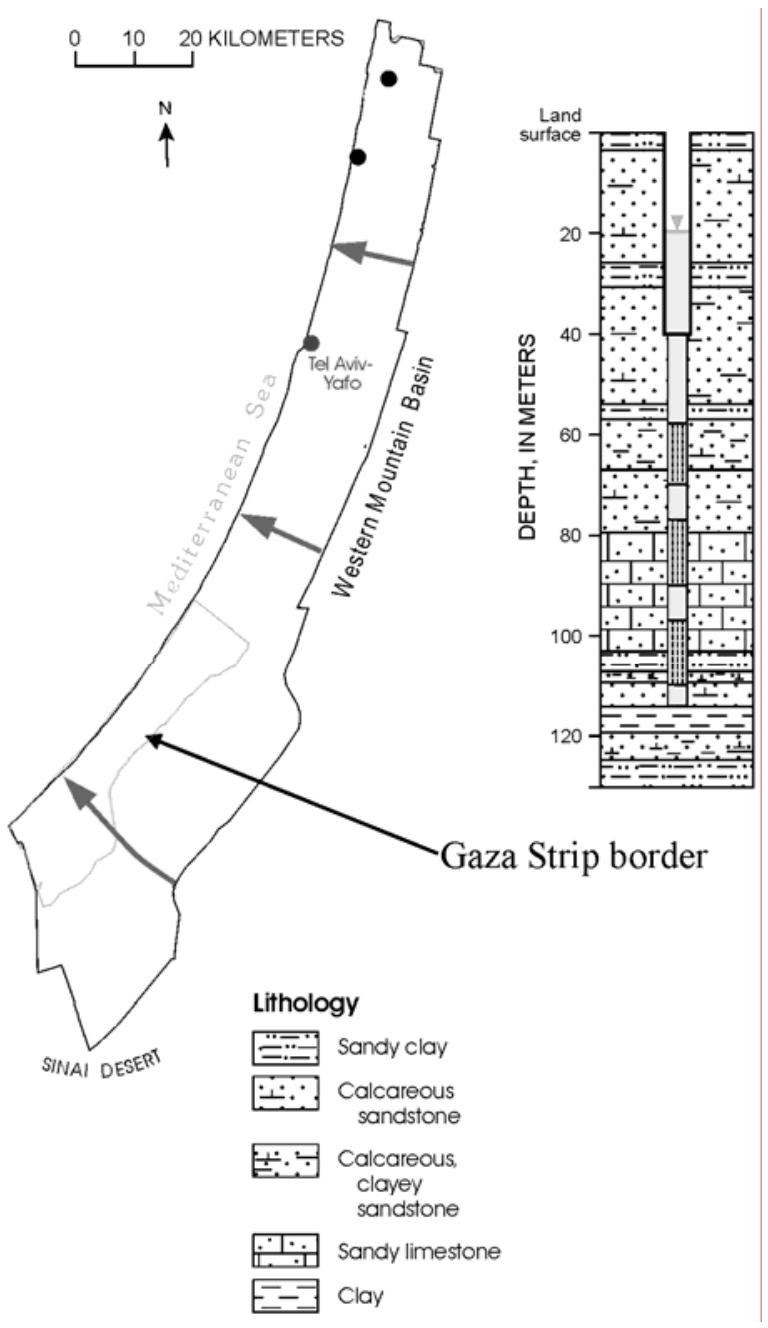

Figure 2. Coastal aquifer basin and lithology (Baalousha 2006)

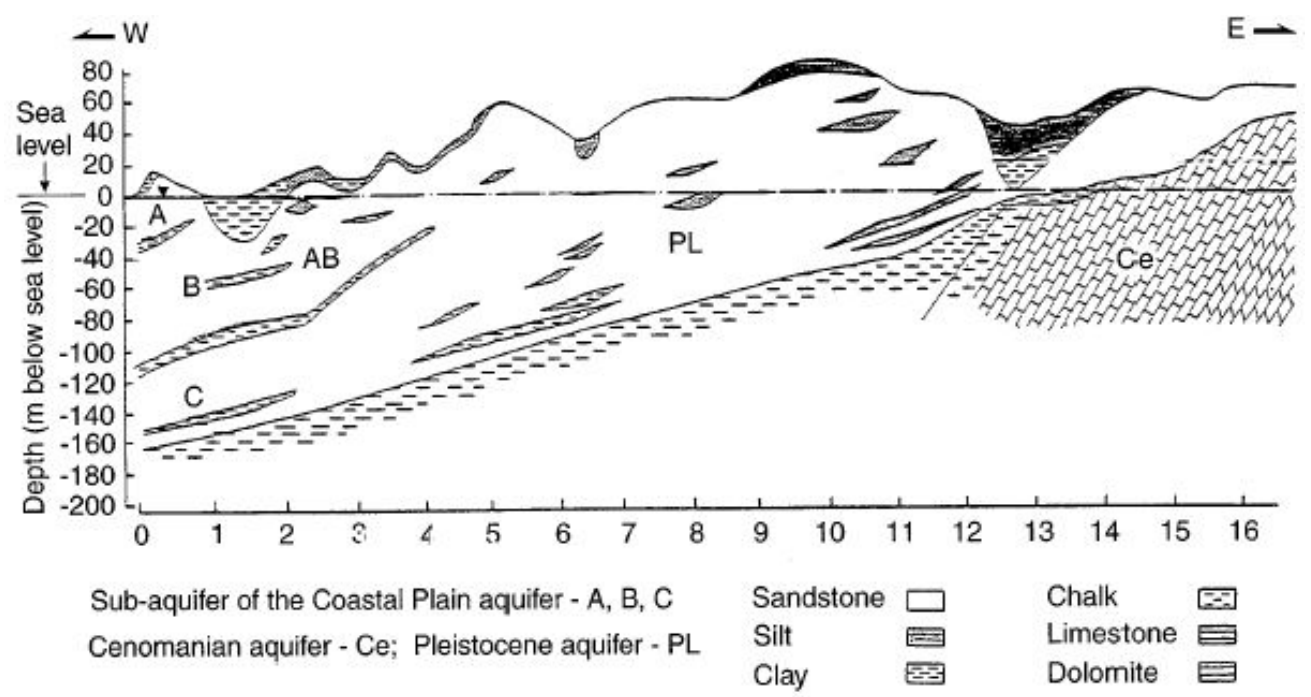

Figure 3. Typical cross-section in the study area (Baalousha 2003)

\section{SOURCES OF NITRATE IN GROUNDWATER IN THE GAZA STRIP}

The lateral groundwater inflow to the Gaza Strip aquifer does not contain any nitrate pollution (Vengosh et al., 2005). Therefore, it is believed that the nitrate in groundwater is of anthropogenic origin. Application of fertilizers and pesticides in agricultural areas is the main 
reason of increasing nitrate level in groundwater (Ronen and Magaritz, 1985). In addition to agricultural activities, nitrogen released from wastewater discharge plays a big role in aquifer pollution. Different factors affect the amount of nitrate pollution in groundwater resulted from nitrogen load at the land surface. Such factors could be fertilizers and manure application rate, thickness of unsaturated zone, crop management, and form of applied nitrogen (Bohlke, 2002).

About $60 \%$ of the total amount of groundwater in the Gaza Strip is polluted and not potable according to WHO standards (PWA, 1999). As pumping increases, the aquifer becomes more deteriorated, as brackish water encroach the aquifer. For instance, according to Palestinian Water Authority (PWA) records, the concentration of chloride has recently reached more than $1000 \mathrm{mg} \mathrm{l}^{-1}$ in many locations. High chloride concentrations have been detected in Gaza City and the southern area. In Khan Yunis City, seawater intrusion has been detected (Yakirevich, et al. 1998), causing high chloride concentrations.

Nitrate $\left(\mathrm{NO}_{3}\right)$ has also been detected at increased concentrations reaching $300 \mathrm{mg} \mathrm{I}^{-1}$, especially in Khan Yunis area. It is believed that the leached wastewater from cesspits in this area is responsible for these increased concentrations of nitrate. In the northern part of the Gaza Strip (i.e. Bait Lahia) where the wastewater treatment plant is overloaded and wastewater has been flooding a wide area around, high concentrations of nitrate have been detected in groundwater.

The natural cycle of nitrogen can be severely disturbed by human activities and leads to harmful impact on the environment. According to Vengosh et al. (Vengosh et al., 2005), nitrate pollution in the Gaza Strip is derived from agricultural return flow, and wastewater discharge. Therefore, nitrate sources in groundwater can be classified into two categories: point sources and non-point sources.

\subsection{Wastewater leakage (point sources)}

Point source pollution represents those activities where pollutants are routed directly into receiving water bodies. Leakage of wastewater from treatment plants that are over-loaded, cesspits in non-sewered areas, landfills, and industrial spillages are considered as "point sources". The leaked wastewater is rich in nitrogen and can be decomposed in aerobic conditions in the upper soil. As a result, nitrate infiltrates the water table and contributes in raising the nitrate level in groundwater. In the study area, there are three treatment plants: Bait Lahia treatment plant in the north, Gaza City treatment plant located southern Gaza City, and Rafah treatment plant in the south of the Gaza Strip. The northern one serves the northern part of the Gaza Strip. This plant is overloaded and the surplus sewage covers the sand duns around, causing environmental damage of the soil and groundwater. The Gaza City treatment plant recharges the aquifer with 3.6 million $\mathrm{m}^{3}$ of treated wastewater annually, and the rest $\left(11.7\right.$ million $\left.\mathrm{m}^{3}\right)$ is being discharged to the sea. The effluent of Rafah treatment plant is being discharged to the sea. Sewerage outflow in different communities exceeds the capacity of the existing treatment plants, and there are many technical and environmental problems associated with these plants. Approximately $70-80 \%$ of the domestic wastewater produced in the Gaza Strip is discharged into the environment without treatment through leakages and overloaded treatment plants.

In addition to leakage from treatment plants, leakage of wastewater by other means is very common in the Gaza Strip. Only $60 \%$ of the urban areas are connected to sewerage network (United Nations, 2003). This means many areas are discharging the wastewater using cesspits, especially in the densely populated refugee camps. Sewerage collected from cesspits is very often discharged to open fields without treatment, and thus, destroying the upper soil and increasing the aquifer pollution.

\subsection{Agricultural sources (non point sources)}

Non-point source water pollution, once known as "diffuse" source pollution, arises from a broad group of human activities for which the pollutants have no obvious point of entry into receiving watercourses. Agricultural activities are usually considered as "the nonpoint sources 
of nitrate pollution". As a result of the agricultural activities, different types of fertilizers and pesticides are usually applied. Organic, including manures, and inorganic types of fertilizers are used in the Gaza Strip. The applied fertilizers in agricultural areas is about 12,000 tons, of which 3,500 tons are chemical fertilizers and the rest are organic fertilizers (manure from cattle and poultry) (PNIC, 2005). As there is no proper guidance, farmers apply fertilizers intensively and more than the actual crop demand. Consequently, the excess of nitrogen leaches beneath the upper soil and infiltrates to the aquifer in form of nitrate. As a result, pollutants from agricultural activities are scattered in wide areas.

\section{METHODOLOGY}

Water samples from 63 wells, representing a wide range of land uses in the entire area of the Gaza Strip, were collected and analysed. Sampling points are shown in Figure 1. Collection of samples and analysis were done within one week in October 2002. Different municipalities are operating the municipal wells and use them for domestic water supply. Depths of the wells vary according to depth to water table, but they are generally between 30 to $50 \mathrm{~m}$. Samples were taken at well-head directly from the pump, and were collected in tight capped high quality polyethylene bottles and were immediately transported to the laboratory under low temperature conditions in iceboxes. The samples were stored in the laboratory at $4 \circ \mathrm{C}$ until processed and analyzed.

Chemical analysis of the collected samples was carried out the laboratory of Ministry of Health $(\mathrm{MOH})$ and Ministry of Agriculture (MOA). The cations in the water samples were measured by inductively coupled plasma, the anions by ionic chromatography, and the bicarbonate by titration. Table 1 shows the results of the chemical analysis of the collected samples. The wells were classified into two groups based on the ratios of different ions and sources of nitrate at these wells. This will be explained later in this study. Chemical analysis was carried out to determine the sources of nitrate pollution in groundwater, based on major ion chemistry analysis.

\section{ANALYSIS AND DISCUSSION}

Chemical composition of groundwater in the Gaza Strip varies mainly according to land use. Agricultural areas are associated with water rich of calcium because of liming and the application of fertilizers. Residential areas, where leakage of wastewater takes place, produces water that is more enriched in sodium, nitrate and chloride. As the wastewater treatment plants are relatively away from the sea, the chloride concentration in the vicinity of these plants are probably resulted from wastewater and not seawater intrusion. Chloride concentration in wastewater in the Gaza Strip varies between 250 to $550 \mathrm{mg} / \mathrm{l}$ (Nashashibi and Van Duijl, 1995). As chloride is a conservative parameter, no changes in chloride concentrations occur through infiltration of pollutants.

Figure 4 shows the distribution of groundwater samples on a ternary plot of sodium, calcium, and magnesium. It is clear from the figure that some wells have higher $\mathrm{Na} / \mathrm{Ca}$ ratio than others. Samples from group 1 of wells (Table 1 ) are characterised by high $\mathrm{Na} / \mathrm{Ca}$ ratio as appears in Figure 4. They are also characterised by relatively high chloride concentrations, that is, low $\mathrm{Na} / \mathrm{Cl}$ ratio, as shown in Figure 5 . The chloride concentrations in wells of group 1 vary between $35 \mathrm{mg} \mathrm{I}^{-1}$ and $1127 \mathrm{mg} \mathrm{I}^{-1}$, and their nitrate concentrations vary between 16 to $316 \mathrm{mg} \mathrm{l}^{-1}$. Amongst this group, some wells have nitrate concentrations less than $50 \mathrm{mg} \mathrm{I}^{-1}$. Despite their low nitrate concentration, the sodium level of some of these wells is high more than the sea " $\mathrm{Na} / \mathrm{Cl}$ ratio in the Mediterranean is 0.86" (Vengosh and Rosenthal 1994). The high sodium concentration of these wells reflects either the displacement of seawater by fresh water (Vengosh et al., 2005) or freshening of the saline lateral groundwater inflow.

The remaining wells are located in residential areas where leakage of wastewater occurs (see well location maps in Figure 1). For example, the L-wells are located in Khan Yunis area where the use of cesspits is very common, as the area is not connected to the sewer system. Therefore, Khan Yunis area has a high-level of nitrate concentration in groundwater (Baalousha, 2003). The P-wells are located in Rafah refugee camp where leakage of wastewater takes place, and the R-wells are located in the vicinity of the Shati Camp near 
Gaza City, where leaching of wastewater takes place. Pollution with domestic wastewater results in high concentrations of sodium and low concentrations of magnesium and calcium. As a result, $\mathrm{Na} / \mathrm{Ca}$ and $\mathrm{Na} / \mathrm{Mg}$ ratios are high in this type of polluted water (Figure 4).

Table 1. Chemical analysis of groundwater $\left(\mathrm{mg} \mathrm{I}^{-1}\right)$ in the Gaza Strip in October 2002.

\begin{tabular}{|c|c|c|c|c|c|c|c|c|c|c|}
\hline Agri. No. ${ }^{+}$ & $\mathrm{NO}_{3}$ & $\mathrm{Ca}$ & Mg & $\mathrm{Na}$ & $\mathrm{K}$ & $\mathrm{HCO}_{3}$ & $\mathrm{Cl}$ & $\mathrm{SO}_{4}$ & TDS & Group* \\
\hline$A / 180$ & 72.71 & 95.5 & 14.96 & 52.59 & 1.3 & 300.3 & 84.7 & 28.3 & 550 & 2 \\
\hline$A / 185$ & 98.67 & 63 & 23.91 & 65.12 & 6.9 & 256 & 84.7 & 43.3 & 609 & 2 \\
\hline $\mathrm{C} / 127$ & 54.28 & 54.7 & 18.03 & 63.11 & 1.9 & 211 & 77.7 & 17.2 & 462 & 2 \\
\hline $\mathrm{C} / 128$ & 50.88 & 68.5 & 30.55 & 202 & 2.4 & 297.2 & 247 & 41.9 & 851 & 1 \\
\hline $\mathrm{C} / 76$ & 77.29 & 127 & 41 & 250 & 3.1 & 485.1 & 579 & 37.3 & 1525 & 1 \\
\hline $\mathrm{C} / 79$ & 89.09 & 113 & 38.45 & 298 & 3.1 & 442 & 473 & 67.5 & 1425 & 1 \\
\hline $\mathrm{D} / 60$ & 138.9 & 116 & 8.01 & 57.8 & 2.8 & 322 & 118 & 57.2 & 671 & 2 \\
\hline $\mathrm{D} / 67$ & 29.35 & 52.2 & 10.92 & 35.06 & 1.5 & 175.6 & 35.3 & 16.3 & 330 & 2 \\
\hline $\mathrm{D} / 67 \mathrm{~B}$ & 46.02 & 67.5 & 16.17 & 57.5 & 4.6 & 235.3 & 70.6 & 24.3 & 460 & 2 \\
\hline $\mathrm{D} / 68$ & 83.95 & 74.9 & 21.21 & 122.7 & 2.2 & 274.6 & 127 & 64.4 & 584 & 1 \\
\hline D/69 & 105.3 & 100 & 15.73 & 70.12 & 3.4 & 315.9 & 98.8 & 24 & 594 & 2 \\
\hline $\mathrm{D} / 70$ & 91.16 & 96.3 & 20.44 & 49.96 & 7.6 & 324.9 & 98.8 & 38.5 & 536 & 2 \\
\hline $\mathrm{D} / 74$ & 69.32 & 68 & 26.73 & 40.48 & 5.3 & 280.1 & 76.5 & 37.8 & 582 & 2 \\
\hline $\mathrm{D} / 75$ & 154.4 & 93 & 15.32 & 55.22 & 7.8 & 295.7 & 77.7 & 44.7 & 568 & 2 \\
\hline $\mathrm{D} / 76$ & 75.58 & 86.5 & 17.79 & 37.69 & 7.3 & 289.5 & 63.5 & 19.9 & 474 & 2 \\
\hline$E / 1$ & 101.9 & 89.3 & 18.92 & 44.47 & 2.6 & 301.1 & 111 & 34.3 & 580 & 2 \\
\hline$E / 11 A$ & 53.98 & 41.7 & 25.14 & 126.2 & 1.33 & 201.7 & 146 & 13.6 & 671 & 1 \\
\hline$E / 11 B$ & 178.8 & 97.8 & 25.88 & 71.03 & 2.2 & 351 & 113 & 99 & 671 & 2 \\
\hline$E / 11 C$ & 38.94 & 34 & 24.31 & 125.7 & 1.16 & 185.2 & 111 & 65.2 & 577 & 1 \\
\hline$E / 138$ & 66.67 & 82.5 & 21.09 & 78.62 & 1.68 & 293 & 125 & 27.2 & 596 & 2 \\
\hline$E / 142$ & 99.12 & 94.4 & 17.78 & 39.87 & 1.6 & 309.1 & 90.4 & 48.1 & 586 & 2 \\
\hline$E / 15$ & 46.51 & 54.7 & 23.17 & 153 & 3.9 & 232.1 & 177 & 56.8 & 751 & 1 \\
\hline$E / 154$ & 59 & 133 & 26.93 & 207 & 3 & 442.9 & 466 & 52 & 1121 & 1 \\
\hline$E / 156$ & 133 & 80.8 & 26.81 & 81.5 & 3 & 312.3 & 153 & 34.8 & 733 & 2 \\
\hline$E / 157$ & 96.74 & 87.7 & 32.34 & 149 & 5 & 352.4 & 177 & 64.4 & 841 & 1 \\
\hline$E / 4$ & 62.54 & 65.5 & 22.81 & 41.29 & 2.8 & 257.6 & 69.6 & 24.7 & 492 & 2 \\
\hline$E / 61$ & 70.8 & 94.4 & 20.9 & 81.5 & 5.2 & 322 & 141 & 56.6 & 649 & 2 \\
\hline$E / 9$ & 30.38 & 44.9 & 19.12 & 85 & 2.6 & 191 & 98.8 & 23.1 & 490 & 1 \\
\hline$E / 90$ & 186.4 & 151 & 20.47 & 95 & 3.2 & 460.5 & 139 & 67.2 & 971 & 2 \\
\hline $\mathrm{G} / 30$ & 189.1 & 208 & 58.89 & 653.4 & 1.72 & 762.6 & 974 & 349 & 2579 & 1 \\
\hline $\mathrm{J} / 1$ & 38.35 & 45.9 & 19.43 & 175.1 & 1.6 & 194.8 & 188 & 125 & 756 & 1 \\
\hline $\mathrm{J} / 2$ & 54.57 & 30.6 & 21.68 & 196.5 & 1.2 & 165.8 & 188 & 104 & 767 & 1 \\
\hline $\mathrm{L} / 127$ & 316.2 & 156 & 56.37 & 349.7 & 2.6 & 621.7 & 668 & 161 & 1810 & 1 \\
\hline $\mathrm{L} / 159$ & 271.8 & 188 & 35.68 & 293.6 & 4.8 & 616.6 & 487 & 273 & 1774 & 1 \\
\hline $\mathrm{L} / 159 \mathrm{~A}$ & 165.6 & 93.5 & 31.58 & 154 & 2.7 & 363.9 & 237 & 95 & 1048 & 1 \\
\hline $\mathrm{L} / 176$ & 113.3 & 36.9 & 50 & 517.6 & 3.3 & 94.96 & 744 & 260 & 1984 & 1 \\
\hline $\mathrm{L} / 178$ & 59.88 & 68.9 & 40.29 & 992.5 & 4.3 & 338.1 & 1127 & 680 & 3205 & 1 \\
\hline $\mathrm{L} / 181$ & 16.45 & 16.2 & 11.3 & 840 & 0.9 & 86.94 & 104 & 50.9 & 431 & 1 \\
\hline $\mathrm{L} / 41$ & 215.9 & 66.4 & 40.96 & \begin{tabular}{|l}
938.2 \\
\end{tabular} & 0.75 & 334.8 & 988 & 526 & 2800 & 1 \\
\hline $\mathrm{L} / 43$ & 182.9 & 166 & 64.33 & 436 & 3.9 & 679.4 & 696 & 240 & 2170 & 1 \\
\hline $\mathrm{L} / 86 \mathrm{~B}$ & 35.69 & 77.4 & 39.43 & 778.4 & 5.4 & 355.8 & 1064 & 281 & 2700 & 1 \\
\hline L/87 & 301.8 & 154 & 57.48 & 565.5 & 4.1 & 621.5 & 918 & 302 & 2800 & 1 \\
\hline L/87Desal & 103.2 & 3.26 & 9.6 & 420 & 5.0 & 47.74 & 127 & 56.6 & 366 & 1 \\
\hline $\mathrm{P} / 124$ & 131.9 & 95.2 & 35.24 & 78.62 & 7.11 & 383.2 & 424 & 95.2 & 1217 & 2 \\
\hline $\mathrm{P} / 144$ & 32.67 & 27.2 & 15.15 & 209 & 1.56 & 130.4 & 264 & 57 & 732 & 1 \\
\hline
\end{tabular}


Table 2. Chemical analysis of groundwater $\left(\mathrm{mg} \mathrm{l}^{-1}\right)$ in the Gaza Strip in October 2002 (continued)

\begin{tabular}{|c|c|c|c|c|c|c|c|c|c|c|}
\hline Agri. No. $^{+}$ & $\mathbf{N O}_{3}$ & $\mathbf{C a}$ & $\mathbf{M g}$ & $\mathbf{N a}$ & $\mathbf{K}$ & $\mathbf{H C O}_{3}$ & $\mathbf{C l}$ & $\mathbf{S O}_{4}$ & TDS & Group$^{*}$ \\
\hline $\mathrm{P} / 145$ & 58.41 & 51 & 16.73 & 227.1 & 1.21 & 196.4 & 264 & 76.7 & 854 & 1 \\
\hline $\mathrm{P} / 146$ & 20.13 & 24.7 & 17.87 & 250 & 1.4 & 135.2 & 160 & 90.7 & 587 & 1 \\
\hline $\mathrm{P} / 15$ & 152.5 & 115 & 39.01 & 480 & 3.61 & 447.6 & 696 & 264 & 1852 & 1 \\
\hline $\mathrm{Q} / 40 \mathrm{~B}$ & 59.59 & 85 & 20.72 & 92.91 & 7.4 & 297.9 & 174 & 51.2 & 761 & 2 \\
\hline $\mathrm{R} / 112$ & 75.22 & 118 & 48.74 & 559.1 & 5.75 & 494.8 & 842 & 132 & 2069 & 1 \\
\hline $\mathrm{R} / 162 \mathrm{~B}$ & 111.5 & 165 & 9.237 & 214 & 3 & 450.8 & 417 & 40.4 & 1214 & 1 \\
\hline $\mathrm{R} / 162 \mathrm{C}$ & 75.81 & 127 & 17.83 & 105.8 & 2.4 & 390.5 & 275 & 45 & 803 & 2 \\
\hline $\mathrm{R} / 162 \mathrm{G}$ & 136 & 97.9 & 50.03 & 376.9 & 10 & 450.8 & 515 & 187 & 1639 & 1 \\
\hline $\mathrm{R} / 162 \mathrm{Ha}$ & 164.6 & 115 & 38.74 & 337 & 9.2 & 446.8 & 501 & 185 & 1590 & 1 \\
\hline $\mathrm{R} / 162 \mathrm{Hb}$ & 151 & 106 & 40.24 & 453 & 21 & 431.7 & 508 & 234 & 1794 & 1 \\
\hline $\mathrm{R} / 162 \mathrm{ia}$ & 113.9 & 150 & 23.93 & 254.7 & 4 & 473 & 452 & 82.2 & 1357 & 1 \\
\hline $\mathrm{R} / 254$ & 61.4 & 55.5 & 24.64 & 341.8 & 4 & 240.2 & 402 & 54.4 & 1214 & 1 \\
\hline $\mathrm{R} / 25 \mathrm{~A}$ & 83.48 & 47.6 & 42.63 & 421.3 & 3.8 & 294.6 & 473 & 230 & 1575 & 1 \\
\hline $\mathrm{R} / 25 \mathrm{C}$ & 147.5 & 60.8 & 49.91 & 787.4 & 2.16 & 357.6 & 932 & 269 & 2600 & 1 \\
\hline $\mathrm{R} / 25 \mathrm{D}$ & 82.33 & 57.9 & 29.14 & 683.7 & 4.4 & 264.9 & 706 & 273 & 2141 & 1 \\
\hline $\mathrm{R} / 271$ & 67.85 & 93 & 19.43 & 221.1 & 10 & 312.6 & 304 & 57.2 & 1083 & 1 \\
\hline $\mathrm{S} / 69$ & 41.59 & 50.2 & 30.14 & 371 & 1.8 & 249.6 & 466 & 175 & 1332 & 1 \\
\hline $\mathrm{R} / 265$ & 47.67 & 59.6 & 20.2 & 119.3 & 1.7 & 232.1 & 184 & 30.3 & 635 & 1 \\
\hline
\end{tabular}

+ Agri. No.: indicates the well agricultural number.

*Group: indicates the well group as shown in Figures 1,4,5.

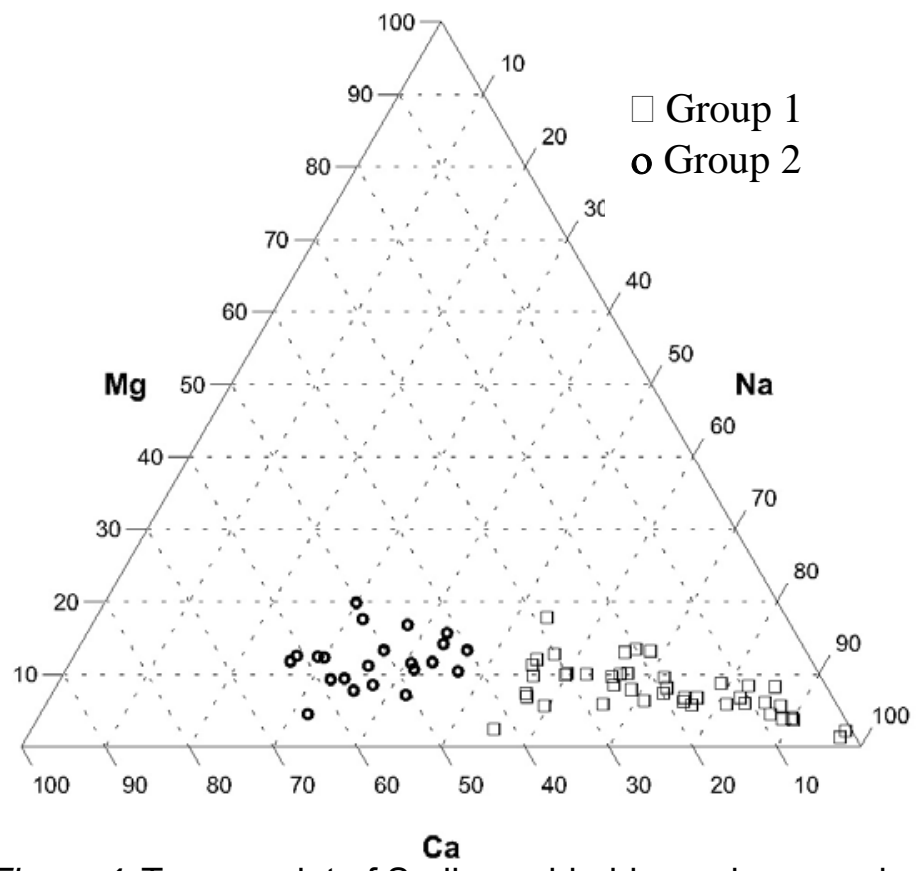

Figure 4. Ternary plot of Sodium, chloride, and magnesium

In addition to their low $\mathrm{Ca}$ concentration, groundwater samples polluted by domestic wastewater have low ratios of $\mathrm{HCO}_{3} / \mathrm{Cl}$ (Figure 5). This indicates that a precipitation of calcite takes place in the unsaturated zone (Kass et al, 2005).

It is well known that domestic wastewater is rich in Na ions. In the Gaza Strip, the concentration of $\mathrm{Na}$ varies between 300 to more than $500 \mathrm{mg} \mathrm{I}^{-1}$ (Nashashibi and Van Duijl, 1995). Chloride concentration in wastewater in the area varies between $250 \mathrm{mg} \mathrm{I}^{-1}$ to more than $500 \mathrm{mg} \mathrm{I}^{-1}$ (Nashashibi and Van Duijl, 1995). Therefore, the $\mathrm{Na} / \mathrm{Cl}$ ratio in wastewater is 
around 1 . Figure 4 suggests that groundwater polluted by wastewater has a low $\mathrm{Na} / \mathrm{Cl}$ ratio. Leakage of wastewater in the vadose zone disturbs the natural balance of the exchangeable cations and results in $\mathrm{Na}-\mathrm{Ca}$ exchange whereby $\mathrm{Na}$ replaces $\mathrm{Ca}$ on the adsorbed sites of clay minerals (Kass et al, 2005). This leads to the reduction of $\mathrm{Na} / \mathrm{Cl}$ and calcite precipitation.

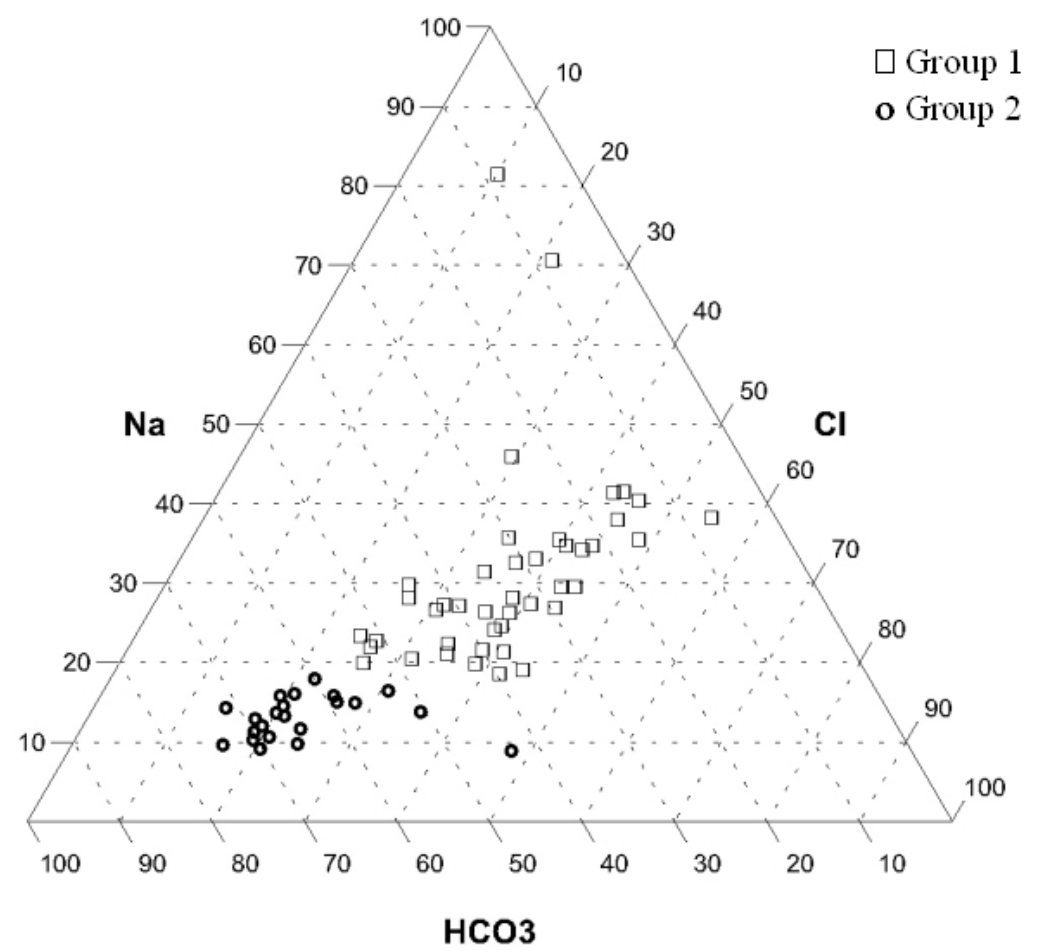

Figure 5. Ternary plot of chloride, sodium and bicarbonate

These chemical patterns are attributed to base exchange in the vadose zone beneath different land use areas. In areas at which wastewater leakage takes place, $\mathrm{Na}$ and $\mathrm{K}$ are absorbed by clay mineral while $\mathrm{Ca}$ and $\mathrm{Mg}$ are released to the water (Appelo and postma, 1993). This explains the high ratios of $\mathrm{Na} / \mathrm{Ca}$, and $\mathrm{Na} / \mathrm{Mg}$ in samples under areas susceptible to wastewater leakage.

Samples from group 2 of wells represent another pattern of chemical composition. These wells are characterised by high value of $\mathrm{HCO}_{3} / \mathrm{Cl}$. As shown in Figure 1 , these wells are located in areas of agricultural activity. The high carbonate concentration might result from dissolution of carbonate in the unsaturated zone.

Spatial distribution of nitrate concentration is shown in Figure 6. The contour map was prepared based on interpolation of measurements from the filed. The nitrate concentration varies between 50 and $420 \mathrm{mg} \mathrm{l}^{-1}$ as shown in Figure 6 . The high nitrate concentration exists beneath the highly populated areas and heavy agricultural activities areas (refer to Figure 1).

This dissolution process could be induced by exchange reaction in which $\mathrm{Ca}$ is removed from water. This explains the low concentration of $\mathrm{Ca}$ in these wells as shown in Figure 4. It is assumed that the high nitrate concentration in these wells is caused by agricultural activities. Moreover, groundwater is characterized by a certain Ca-Mg- $\mathrm{NO}_{3}$ composition with positive correlations between nitrate and $\mathrm{Ca}, \mathrm{Na}$, and $\mathrm{Mg}$. This correlation is shown in Figure 6 where the positive correlations between nitrate and calcium, magnesium and sodium are illustrated.

The student t-test was used to check the null hypothesis of "no correlation" against the alternative hypothesis. In all cases, a positive correlation between $\mathrm{NO}_{3}$ and $\mathrm{Ca}, \mathrm{Na}$, and $\mathrm{Mg}$ was detected with a $95 \%$ of confidence. The results of statistical analysis are shown in Table 2. The p-value in all three tests is small, which supports the argument of rejection of the null hypothesis. The relatively low correlation coefficient between $\mathrm{Na}$ and $\mathrm{NO}_{3}$ is a result of $\mathrm{Na}-\mathrm{Ca}$ exchange in the unsaturated zone, which leads to decrease of $\mathrm{Na}$ concentration. 


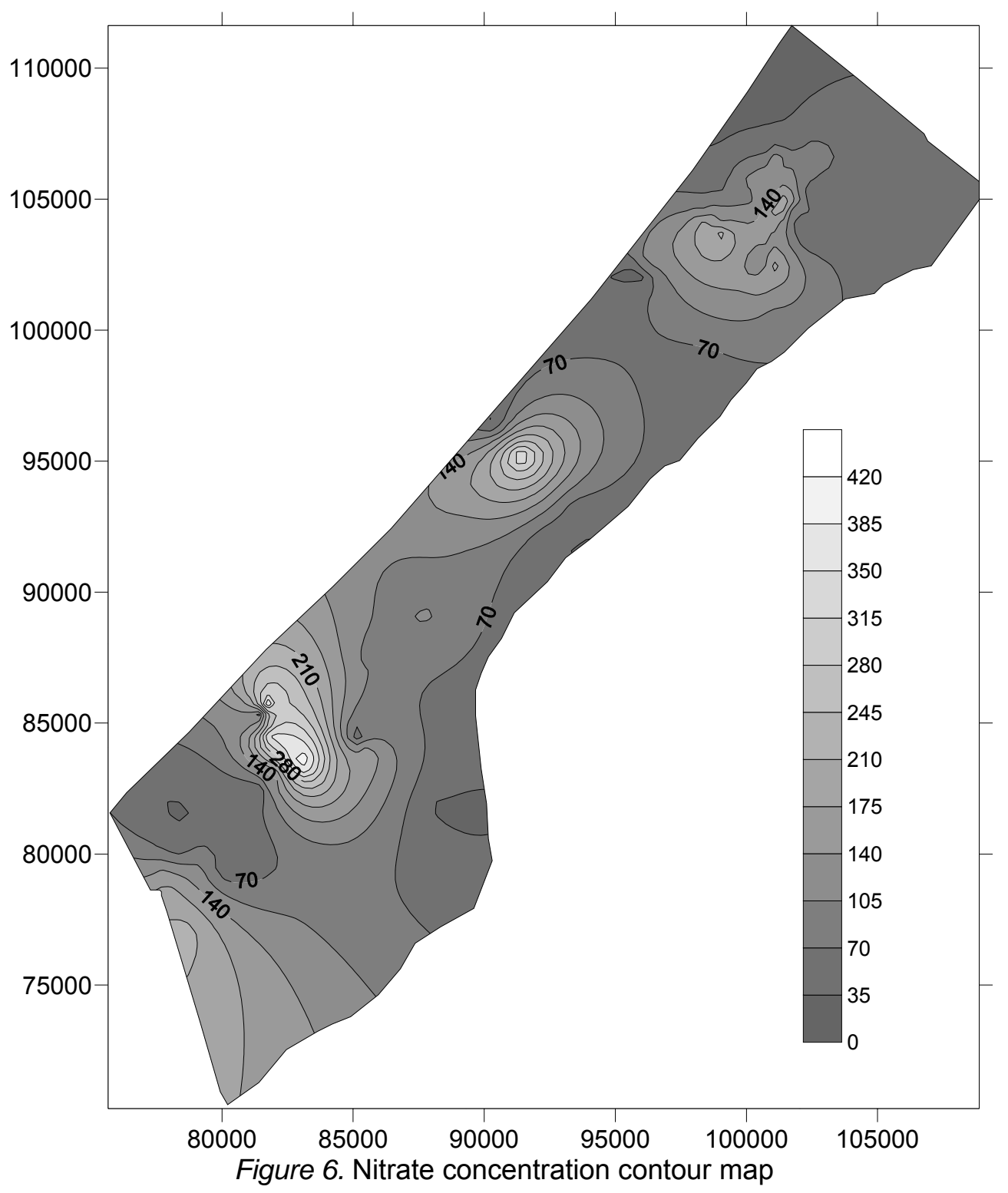

Table 3. Correlation and hypothesis test between $\mathrm{NO}_{3}, \mathrm{Ca}, \mathrm{Na}$, and $\mathrm{Mg}$.

\begin{tabular}{|l|c|c|c|}
\hline \multirow{2}{*}{ Statistics } & \multicolumn{3}{|c|}{ Parameter } \\
\cline { 2 - 4 } & $\mathbf{C a}$ & $\mathbf{N a}$ & $\mathbf{M g}$ \\
\hline Correlation coefficient with $\mathbf{N O}_{3}$ & 0.678 & 0.244 & 0.651 \\
\hline 95\% Confidence Interval & 0.467 to 0.815 & -0.069 to 0.513 & 0.430 to 0.799 \\
\hline t-test & 5.754 & 1.57 & 5.36 \\
\hline P-value & 0 & 0.125 & 0 \\
\hline
\end{tabular}

It is noticeable that nitrate concentration in groundwater resulted form wastewater discharge is higher than that in agricultural areas. This can be explained as a result of the high decline in agricultural areas, the wide urbanisation in the last ten years, and high nitrogen content in wastewater. 

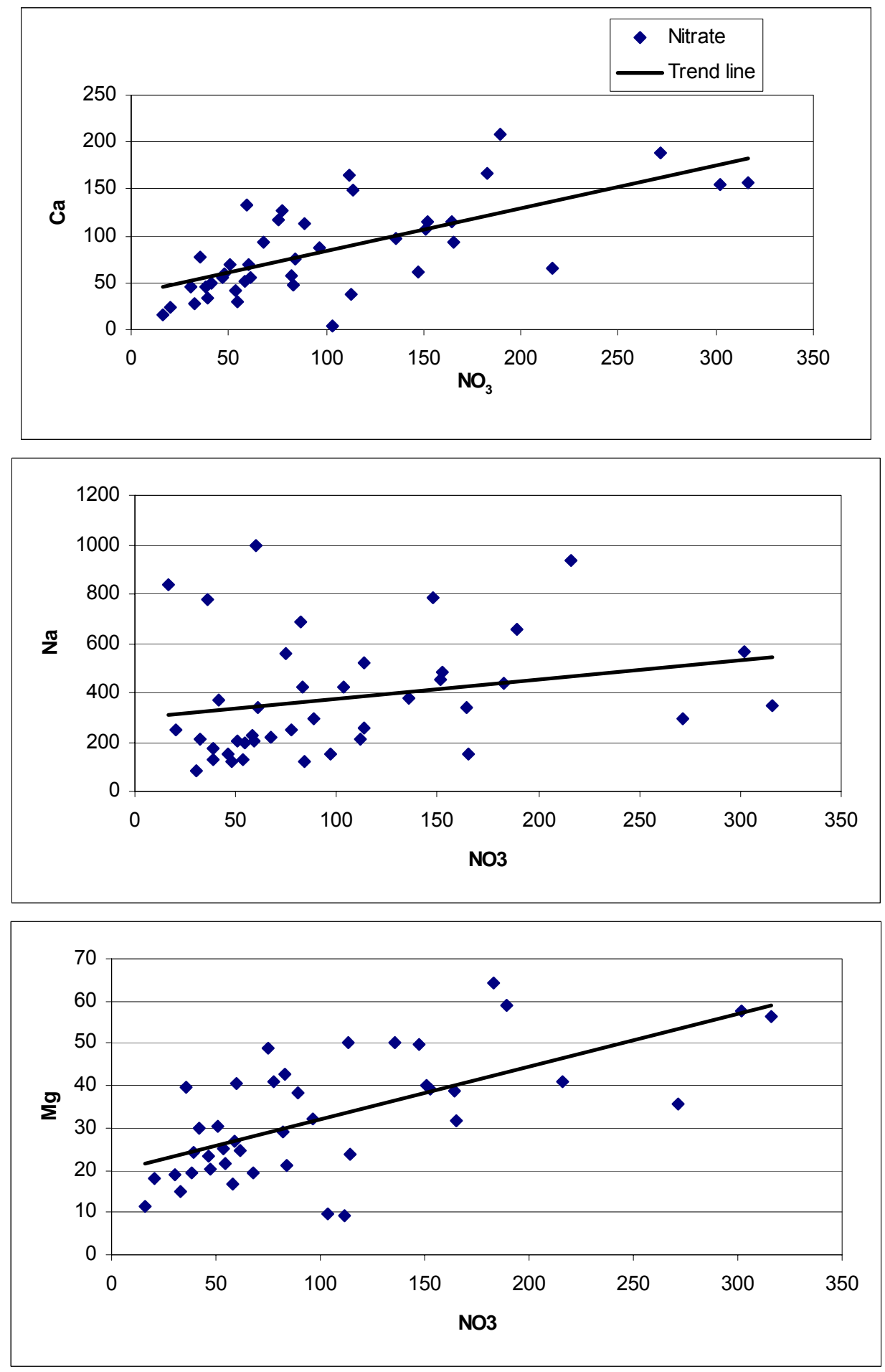

Figure 7. Correlation between $\mathrm{NO}_{3}-\mathrm{Ca}, \mathrm{NO}_{3}-\mathrm{Na}$, and $\mathrm{NO}_{3}-\mathrm{Mg}$

\section{CONCLUSION}

Two sources of nitrate, wastewater and agricultural activities, contribute to the groundwater nitrate pollution in the Gaza Strip. Samples of groundwater from 63 wells were collected and analysed. The major ion chemistry analysis was used to define the sources of nitrate in the area of study using different ions ratios (Ternary plots).

The results suggest that the primary source of nitrates in these wells is a function of land use. Since the lateral groundwater inflow has low $\mathrm{Mg}$-Ca concentrations, high-level of these elements in the Gaza aquifer reveals that the pollution is anthropogenic sourced. The most 
severely nitrate polluted area in the Gaza Strip is Khan Yunis at which the maximum nitrate concentrations were recorded (more than $400 \mathrm{mg} \mathrm{l}^{-1}$ ). Despite the intensive agricultural activities in the northern and southwestern areas, wastewater discharge has greater affect on nitrate pollution than agriculture. The heavy urbanisation of agricultural land in the Gaza Strip explains these findings.

Groundwater polluted by wastewater has a reduced ratio of $\mathrm{Na} / \mathrm{Cl}$ when compared to $\mathrm{Na} / \mathrm{Cl}$ ratio in wastewater. This suggests that $\mathrm{Na}-\mathrm{Ca}$ exchange takes place in the unsaturated zone and leads to precipitation of $\mathrm{Ca}$. A positive correlation between nitrate concentration and $\mathrm{Ca}$, $\mathrm{Na}$, and $\mathrm{Mg}$ was found particularly in areas polluted with wastewater. This implies that the increase in nitrates is accompanied by increase in other ions. The reason is that the wastewater is rich in $\mathrm{Ca}, \mathrm{Na}, \mathrm{Mg}$ and other ions.

As nitrate pollution is very dangerous for infants, public awareness is very important to avoid the impact of drinking nitrate-polluted water. The nitrate in groundwater cannot be discovered by tasting (like chloride), and it cannot be removed by boiling. Therefore, special care should be taken to ensure that the water does not contain nitrate. When the source of nitrate pollution is determined, the risk of nitrate pollution can be reduced by different means.

A good management program can reduce, but not totally eliminate the risk of nitrate in groundwater. To reduce the excess nitrogen potential, different steps are recommended. Installation of a proper sewer system at the places it does not exist (e.g. Khan Yunis area, refugee camps), and maintenance of the existing sewer system to prevent or minimise leakage of wastewater.

Finally actions should be taken to clean the sand dunes (e.g. northern area) that are flooded with wastewater from the northern treatment plants.

\section{REFERENCES}

Abu Maila Y., El-Nahal I. and Al-Agha M.R. (2004), Seasonal variation and mechanisms of groundwater nitrate pollution in the Gaza Strip. Environmental Geology, 47, 84-90

Al-Agha M.R. and El-Nakhal H.A. (2004), Hydrochemical facies of groundwater in the Gaza Strip, Palestine. Hydrological Sciences Journal, 49 (3), 359-371

Appelo C.A.L. and Postma D. (1993), Geochemistry, groundwater and pollution. Balkema, Rotterdam.

Baalousha, H. (2003). Risk Assessment and Uncertainty Analysis in Groundwater Modelling. Ph.D. Dissertation. Fak. 03 Fak. für Bauingenieurwesen. Signatur: Sz8578. Germany 2003.

Baalousha H. (2005), Using CRD method for quantification of groundwater recharge in the Gaza Strip, Palestine. Journal of Environmental Geology. Vol. 48, pp 889-900

Baalousha H. (2006), Vulnerability assessment for the Gaza Strip, Palestine using DRASTIC. Journal of Environmental Geology. Vol. 50, Pp 405-411

Bohlke J.K. (2002), Groundwater recharge and agricultural contamination. Hydrogeology Journal, 10 (1), 153-179

Chern L., Kraft G. and Postle J. (1999). Nitrate in groundwater - a continuing issue for Wisconsin citizens. Wisconsin: department of natural resources. <http://www.dnr.state.wi.us/org/water/dwg/gw/pubs/Nitrate.pdf>, Last visit: 30.07 .05

EPA, United States Environmental Protection Agency (1996), Drinking water Regulations and Health Advisors. Technical report, Washington DC. USA.

EUROCONSULT and IWACO (1994). Gaza environmental profile, Part one: Inventory of resources. Arnhem/Rotterdam, the Netherlands

Melloul A. and Collin M. (1994): The Hydrological Malaise of the Gaza Strip, Israel Journal of Earth Science, 4, 105-116.

Metcalf and Eddy Consultant Co. (Camp Dresser and McKee Inc. (2000) Coastal aquifer management program, integrated aquifer management plan (Gaza Strip), USAID Study Task 3, Executive Summary, Vol. 1, and Appendices B-G. Gaza, Palestine

Nashashibi M and VanDuijl L.A. (1995), Wastewater characteristics in Palestine. Water Science and Technology, 32 (11), 65-75 1995

Palestinian National Information Centre (PNIC) (2005), The Palestinian Environmental Strategy. Internet report.[http://www.pnic.gov.ps/], last visit: 15.08 .05 
Palestinian Water Authority (PWA) (1999), Water resources and planning department. Gaza Water Resources, Technical report.

PCBS, Palestinian Central Bureau of Statistics (2004), Projected mid-year population in the Palestinian territory by age, sex and region, http://www.pcbs.org/: Internet Report. Last visit: 30.07 .05

Ronen D. and Magaritz M. (1985), High concentration of Solutes at the upper part of the saturated zone (water table) of a deep aquifer under sewage irrigated land, Journal of Hydrology, $\mathbf{8 0}$, 311-323.

U.S. Geological Survey (1998), Overview of Middle East water resources, water resources Palestinian, Jordanian, and Israeli interest. ISBN 0-607-91785-7

United Nations, Governing Council of the United Nations Environmental Programme (2003), Desk Study of the Environment in the Occupied Palestinian Territories. UNEP/GC.22/1.

Vengosh A., Kloppmann W., Marei A., Livshitz Y., Gutierrez A., Banna M., Guerrot C., Pankratov I. and Raanan H. (2005), Sources of salinity and boron in the Gaza strip: Natural contaminant flow in the southern Mediterranean coastal aquifer. Water Resources Research, 41 (1): Art. No. W01013

Vengosh A. and Rosenthal E. (1994), Saline groundwater in Israel: its bearing on water crises in the country. Journal of Hydrology. Vol. 156, pp 389-430.

Yakirevich A., Melloul S., Sorek S., Shaath S. and Borisov V. (1998), Simulation of seawater intrusion into the Khan Yunis area of the Gaza Strip Coastal aquifer, Hydrogeology Journal, 6, 549-559. 